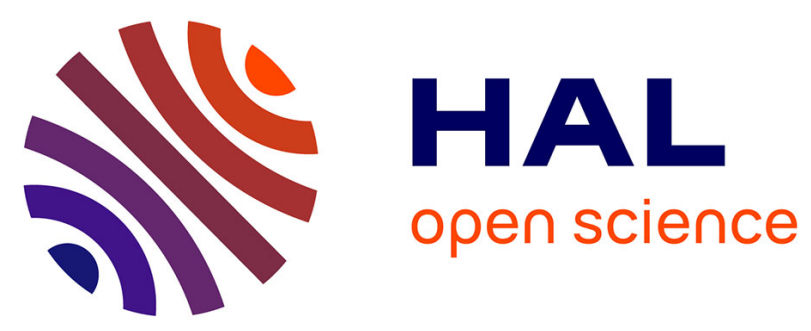

\title{
A striking new genus and species of tiger-moth (Lepidoptera: Erebidae, Arctiinae, Arctiini) from the Caribbean, with molecular and morphological analysis of its systematic placement
}

Benoît Vincent, Mehrdad Hajibabaei, Rodolphe Rougerie

\section{To cite this version:}

Benoît Vincent, Mehrdad Hajibabaei, Rodolphe Rougerie. A striking new genus and species of tiger-moth (Lepidoptera: Erebidae, Arctiinae, Arctiini) from the Caribbean, with molecular and morphological analysis of its systematic placement. Zootaxa, 2014, 3760 (2), pp.289-300. 10.11646/zootaxa.3760.2.8. hal-02639378

\section{HAL Id: hal-02639378 \\ https://hal.inrae.fr/hal-02639378}

Submitted on 28 May 2020

HAL is a multi-disciplinary open access archive for the deposit and dissemination of scientific research documents, whether they are published or not. The documents may come from teaching and research institutions in France or abroad, or from public or private research centers.
L'archive ouverte pluridisciplinaire HAL, est destinée au dépôt et à la diffusion de documents scientifiques de niveau recherche, publiés ou non, émanant des établissements d'enseignement et de recherche français ou étrangers, des laboratoires publics ou privés. 
Version définitive du manuscrit publié dans / Final version of the manuscript published in :

Zootaxa, 2014, 3760(2), 289-300 http://dx.doi.org/10.11646/zootaxa.3760.2

Zootaxa 0000 (0): 000-000

www.mapress.com/zootaxa/

Copyright (C) 2014 Magnolia Press

\section{Article}

http://dx.doi.org/10.11646/zootaxa.0000.0.0

http://zoobank.org/urn:lsid:zoobank.org:pub:00000000-0000-0000-0000-00000000000

\title{
A striking new genus and species of tiger-moth (Lepidoptera: Erebidae, Arctiinae, Arctiini) from the Caribbean, with molecular and morphological analysis of its systematic placement
}

\author{
BENOIT VINCENT ${ }^{12}$, MEHRDAD HAJIBABAEI $^{3} \&$ RODOLPHE ROUGERIE $^{4}$ \\ ${ }^{1} 1$ rue Roger Rameau, 93110 Rosny sous Bois, France.E-mail: amastus@gmail.com \\ ${ }^{2}$ Correspondant, Muséum National d'Histoire Naturelle, Département Systématique et Evolution, USM 602, case postale $n^{\circ} 50$ (Ento- \\ mologie), F-75231 Paris Cedex 05 \\ ${ }^{3}$ Biodiversity Institute of Ontario, University of Guelph, 579 Gordon Street, N1G 2W1, Guelph, Ontario, Canada. \\ ${ }^{4}$ INRA Orléans, UR633, Unité de Recherche en Zoologie Forestière, 2163 Avenue de la Pomme de Pin, CS40001 Ardon, 45075 Orléa- \\ ns Cedex 2, France. E-mail: rrougeri@gmail.com
}

\begin{abstract}
Westindia Vincent, a new genus, is proposed for W. haxairei Vincent, a new species of Neotropical tiger-moth described from Dominican Republic. Habitus, male and female genitalia are described and figured. The systematic position of the new genus within Arctiinae is discussed in light of a comparative morphology and a molecular phylogeny derived from the DNA barcode fragment of the mitochondrial COI gene and of the D2 region of the 28S rDNA gene.
\end{abstract}

Key words: Arctiinae, Arctiini, Dominican Republic, new genus, new species, Westindia, COI, DNA barcoding, 28S rDNA, phylogeny

\section{Résumé}

Westindia Vincent, nouveau genre est proposé pour W. haxairei Vincent, une nouvelle espèce de la sous-famille des Arctiinae, décrite de République Dominicaine. L'habitus, les genitalia mâle et femelle sont décrits et figurés. La position systématique de ce nouveau genre au sein de la sous-famille est discutée sur la base d'une étude morphologique et des résultats d'une analyse phylogénétique du fragment du gène mitochondrial COI utilisé comme code-barres ADN et de la région $\mathrm{D} 2 \mathrm{du}$ gène nucléaire $28 \mathrm{~S}$.

Motsclés: Arctiinae, Arctiini, République Dominicaine, nouveau genre, nouvelle espèce, Westindia, COI, code-barres ADN, 28S, phylogénie

\section{Introduction}

The Dominican Republic is located on the island of Hispaniola, part of the Greater Antilles archipelago in the Caribbean region. The insularity of this country is associated with a mountain system with peaks reaching slightly over 3000 meters, which contributes to the high level of endemicity on the island (Huber et al. 2010; PerezGelabert 2008; Santiago-Valentin \& Olmstead 2004). Within the past decade, as a result of intensive collecting, a variety of new species (Rougerie \& Herbin 2006; Vincent 2005a, b; 2006, 2009, 2011; Vincent et al. 2009 ; Haxaire \& Schmit 2001) and new genera of moths (Thiaucourt 2006; Rawlins \& Miller 2008) have been discovered. Among moths collected in August 2007 was a striking and unique member of the Arctiinae (tiger moths). Here we describe this as a new genus and species, and present morphological and molecular analysis of its systematic placement. 
Version définitive du manuscrit publié dans / Final version of the manuscript published in :

Zootaxa, 2014, 3760(2), 289-300 http://dx.doi.org/10.11646/zootaxa.3760.2

\section{Materials and methods}

Specimen collecting and morphological study. Males and females of the new taxon were collected at mercury vapor light (operated continuously from 0630pm to $0630 \mathrm{am}$ ) near the town of Constanza, in the Dominican Republic. Specimens were killed by injection of ammonia and stored in glassine envelopes. Genitalia were cleared using a heated $\mathrm{KOH}(10 \%)$ solution, stained with chlorazol-black, and mounted on slides in Euparal. Illustrations were made using a digital camera attached to a Leica MZ12 stereomicroscope. The whole body of one male specimen was also cleared using the same protocol. After cleansing of the scales and the internal soft tissues, the metathorax was separated from the mesothorax.

Treatment of the Arctiinae as a subfamily of Erebidae follows Zahiri et al. (2012) and Lafontaine \& Schmidt (2010) with respect to tribal delineations. Genitalic terminology follows Klots (1970), Bendib \& Minet (1998), Zaspel \& Weller (2006), DaCosta \& Weller (2005), and Miller (1991). Institutional acronyms are as follows: AMNH (American Museum of Natural History, New York, USA); BMNH (British Museum of Natural History, London, UK); MNHN (Muséum national d'Histoire Naturelle, Paris, France); MW (Museum Witt, Munich, Germany); RNHL (Rijksmuseum van Natuurlijke Histories, Leiden, Netherlands); SMF (Senckenberg Museum, Frankfurt-am-Main, Germany); UMO (University Museum, Oxford university, Oxford, UK); USNM (National Museum of Natural History, Smithsonian Institution, Washington D.C., USA); ZMHB (Zoologisches Museum, Humboldt Universität, Berlin, Germany).

The first author has visited the aforementioned institutional collections, among others, over the past two decades while conducting taxonomic research on Arctiinae. These institutions hold the type material for two thirds of the Greater Antilles species within the subtribes Arctiina, Phaegopterina and Pericopina. The remaining third is mostly represented by taxa described from Cuba by Grote, and has also been partly examined via photographs of types provided by Jason Weintraub, curator of the Academy of Natural Sciences, Philadelphia, Pennsylvania, USA (ANSP; it is worth noting that many Grote types could not be located, but might be present at the Carnegie Museum, Pittsburgh, Pennsylvania). A description matching the new species described herein was not located in extensive surveys of the available literature (including the descriptions and illustrations by Grote of Cuban species), and the only other specimens located were a single male in the MNHN (lacking collection data) and a series of both sexes in the MW, also from the region of Constanza.

Drawing on the first author's knowledge of Neotropical Arctiinae, the following five genera were carefully selected for comparisons to the new taxon: Ammalo, Elysius, Pseudamastus, Halysidota, and Gorgonidia. Note that the great diversity of genera within the Arctiinae (217 genera listed in the subtribes Phaegopterina, Arctiina, Pericopina and Spilosomina) made this selection challenging. Moreover, the taxon sampling used in available phylogenies for Arctiinae (Jacobson and Weller (2002); Zaspel and Weller (2006); Bendib and Minet (1998) and DaCosta \& Weller (2005)) is too sparse to substantially assist in the selection of candidates for related genera.

Molecular analyses. Tissue samples were processed via DNA barcoding at the Canadian Centre for DNA Barcoding in Guelph (Ontario, Canada), along with many Neotropical tiger moths developed within the iBOL Lepidoptera campaign (see www.lepbarcoding.org for details). DNA extraction, PCR amplification and sequencing followed the protocols described in Vaglia et al. (2008). In addition to the $658 \mathrm{bp}$ fragment of the COI gene, we also amplified and sequenced the D2 expansion segment of the ribosomal large subunit (28S) using the primer pair D2B and D3Ar (Saux et al., 2004). We selected this fragment because sequences of several taxa were already available from another study and because this gene proved to be informative at the tribe and subfamily level in geometrid moths (Abraham et al., 2001; Young, 2006), although it has never previously been used as a phylogenetic marker in the Arctiinae. The taxa used in this study are listed in Table 1. DNA barcodes (COI) were available for a set of 32 species including representatives of all subtribes within the Arctiinae; all records are available at BOLD (www.boldsystems.org) within the public dataset DS-WESTIND1 (dx.doi.org/10.5883/DSWESTIND1). The $28 \mathrm{~S}$ sequences used were available only for 21 species within the last four subtribes (forming the PPCE clade of Jacobson \& Weller (2002) within the Arctiinae). The noctuid moth Helicoverpa armigera [Hübner, 1808] was selected as an outgroup, and is the closest relative to arctiine moths for which sequences of both genes were available (GenBank accession numbers GU350477 and GU654969 for 28S and COI DNA barcode sequences, respectively).

Phylogenetic analysis of DNA sequences. All sequences were aligned manually; 28S rDNA sequences showed no variation in length within our ingroup except for the three included species of Opharus, all of which 
Version définitive du manuscrit publié dans / Final version of the manuscript published in :

Zootaxa, 2014, 3760(2), 289-300 http://dx.doi.org/10.11646/zootaxa.3760.2

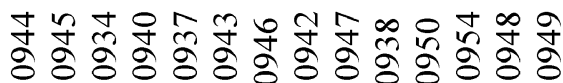

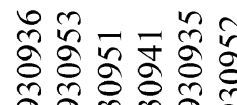

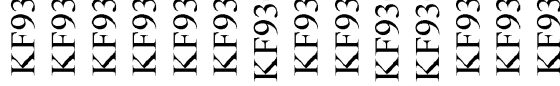

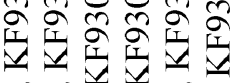

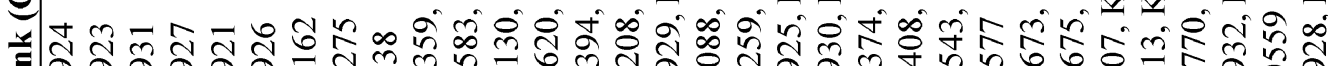

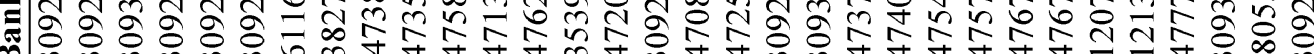

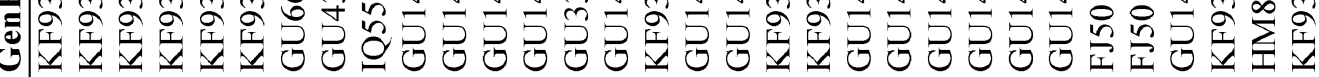

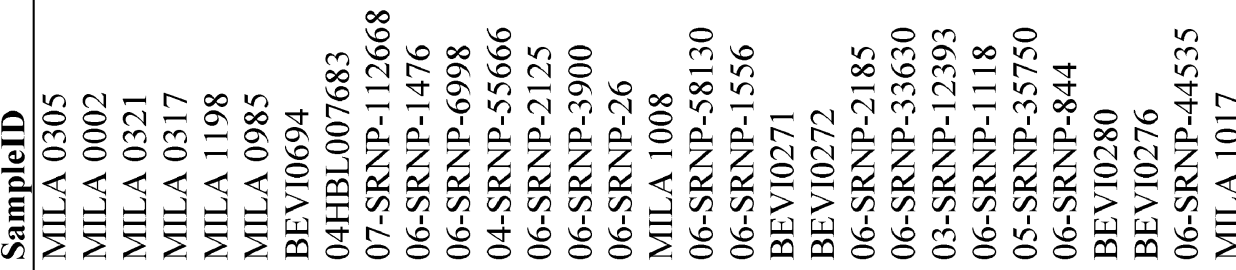

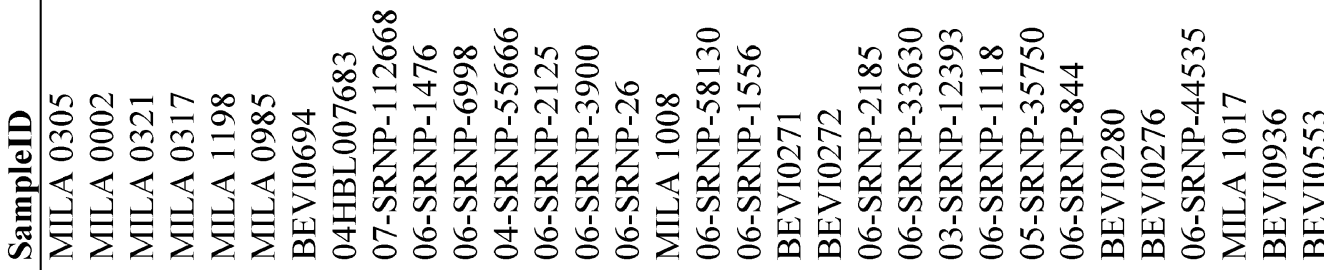

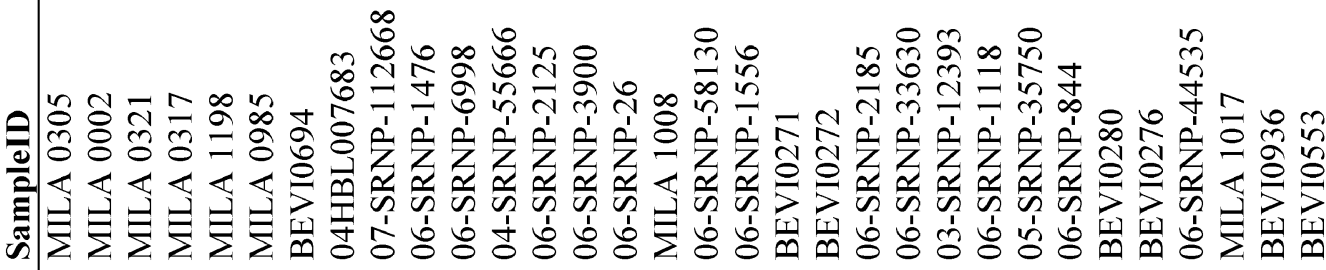

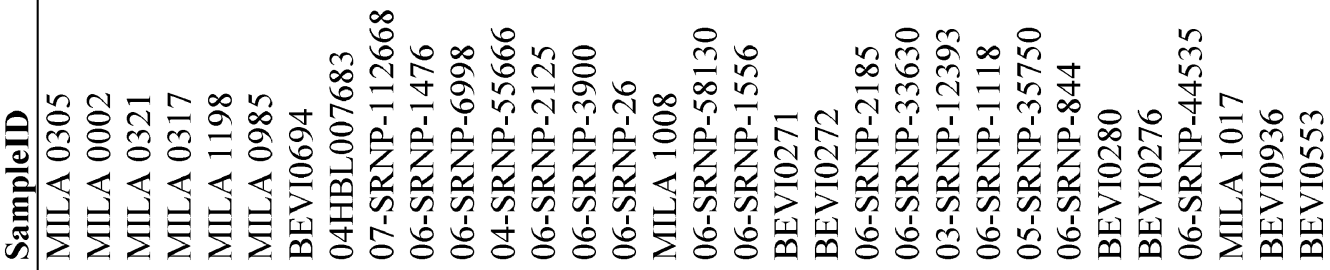

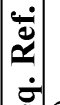

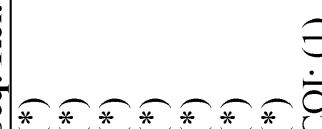
$\overparen{\Xi}$ ชิతป

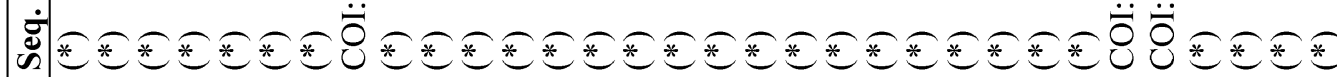
$\infty$

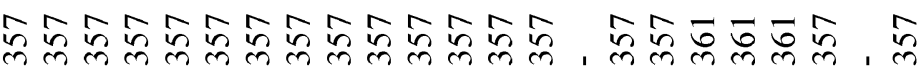

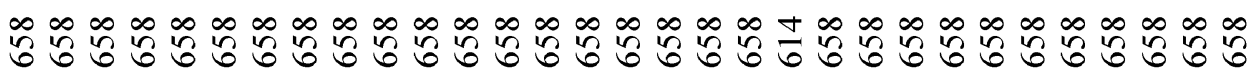
त ठ 表

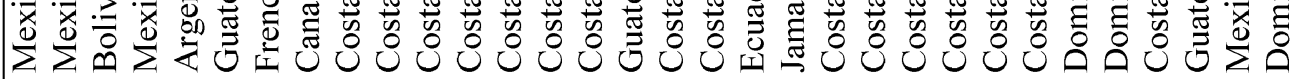

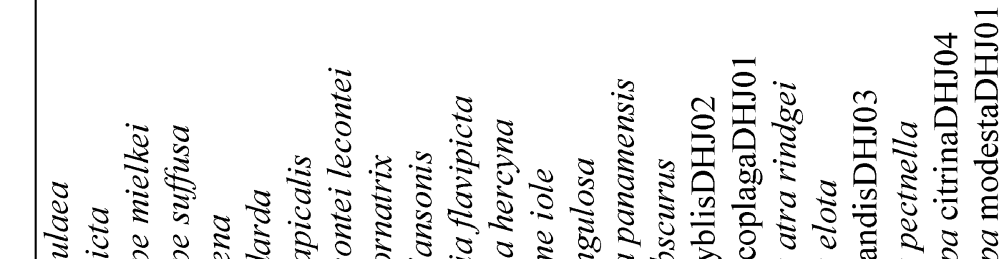

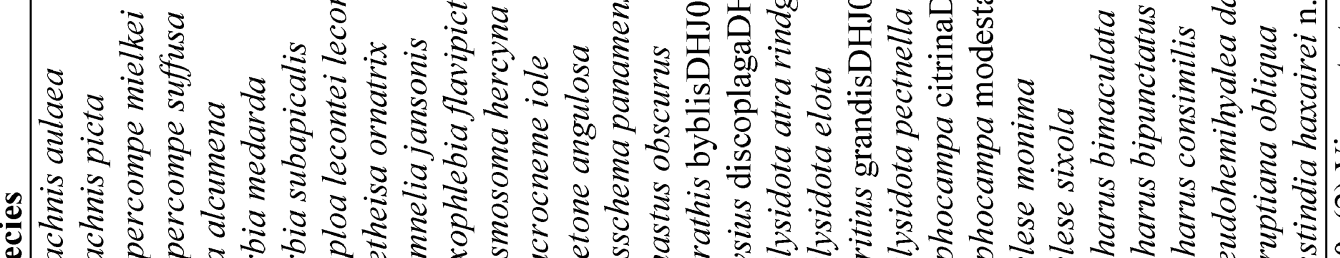

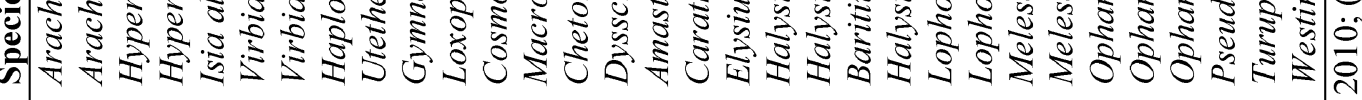


Version définitive du manuscrit publié dans / Final version of the manuscript published in :

Zootaxa, 2014, 3760(2), 289-300 http://dx.doi.org/10.11646/zootaxa.3760.2

have a 4 bp insertion (TTTA) in position 184 of the fragment sequenced, making the alignment with the rest of the sequences straightforward and unambiguous. The sequence for Helicoverpa armigera only differed in length by the presence of a $1 \mathrm{bp}$ insertion in position 300 of the amplicon. Our analyses considered two datasets: (1) the new taxon +20 species in 14 genera within subtribes Pericopina, Phaegopterina, Ctenuchina, and Euchromiina (PPCE) for which sequence data were available for both genes (COI, 28S; see Table 1); and (2) the same dataset augmented by 11 species for which only COI sequences are available - this dataset comprises 32 taxa in total, representing all Arctiinae subtribes (PPCE + Callimorphina and Arctiina). For dataset (1), we analyzed both genes separately and combined; for dataset (2) we analyzed COI sequences separately, as well as a combination of COI $+28 \mathrm{~S}$ with missing data for $28 \mathrm{~S}$ in 11 taxa. Sequences were analyzed using maximum likelihood (ML) and maximum parsimony (MP) methods. MP analyses were carried out in MEGA 5 (Tamura et al., 2011) including all sites and using the Close Neighbor Interchange (CNI) algorithm, with search level 2 and 30 initial trees. The stability of each node was evaluated through a 1000 bootstrap (BS) re-sampling. ML phylogenetic analyzes were performed using RAxML v.7.2.7 (Stamatakis, 2006; Stamatakis et al., 2008) implemented on the CIPRES Portal v. 3.1 (http:// www.phylo.org) at the San Diego Supercomputer Center (Miller et al., 2009), using the GTRCAT model and inferring confidence values through bootstrapping until the stopping criteria are met (Pattengale et al., 2010). The dataset was partitioned by gene (COI / 28S) or alternatively considering COI codon positions in a partition as follows: COI nt1-2 / COI nt3 / 28S.

\section{Systematic Part}

\section{Westindia Vincent, new genus}

Figs. 1-5

Type species: Westindia haxairei Vincent, new species by monotypy

Diagnosis. It proved impossible to associate the new species unequivocally to an already existing genus with the members of which it would share derived diagnostic characters. We describe here what we consider to be the main diagnostic features of this new genus. However, because we establish a monospecific genus, it is impossible to predict which ones of the unique characters described below may be potentially diagnostic at the genus level if other related species are discovered in the future. The higher placement of the new genus within Phaegopterina is assessed below. Westindia n. gen. can be distinguished externally from all other known Arctiinae by its wing pattern. The combination of an orange forewing with two ivory-white transverse bands and three longitudinal grey streaks, white hindwings and a wingspan greater than $50 \mathrm{~mm}$ is unique among the subfamily. Structurally the following combination of characters is diagnostic: hindwing with M2 strongly stalked with M3; male genitalia with a wrinkled scaphium and valves bifid characterized by a deep notch.

Description. Male (Fig. 1). Head. Labial palpi thin and strongly curved upward. First segment strongly curved upward. Second segment thinner, slightly curved and longer than the first. Third segment short and rounded. Proboscis longer than thorax with medium-sized sensillae at its tip. Eyes large without interfacetal setae. Ocellus present. Antennae with 87 flagellomeres, each bearing a pair of dorsal setae and a dense tuft of golden bristles ventrally. This tuft disappears progressively in the apical third. Thorax. Prothoracic legs with epiphysis foliate, apically acute, less than half the length of the tibia. Meso- and metathoracic legs with one and two pairs of tibial spurs, respectively; the spurs smooth, medium-sized and all equal in length. Tympanal Pocket IV present and closed ventrally. Metepisternal tympanal organ present and well developed. Patagia and tegulae developed and covered with long scales. Forewing. Elongate, narrow with apex acute. Venation is of the quadrifid type with M3 in contact with M2; CuA1 and M3 are separate. Hindwing. Reduced and narrowed; its apex acute. Vein M2 strongly stalked with M3; Sc+R1 very thin where it reaches the costal margin. Abdomen. Large and tapered, entirely orange without distinguishable markings. Male terminalia (Figs. 2-3 ; 5-7). Eighth tergum rectangular, slightly sclerotized and prominent posteriorly. Eighth sternum trapeziform and as long as seventh sternum. Uncus and tegumen narrow and elongated. Tuba analis twice as wide as the tegumen at its base and extending beyond the apical end of the uncus. Scaphium sclerotized, concave and tongue-shaped (Fig. 5). Valvae short and symmetrical with a large notch separating two branches: one dorsal, with a very pointed tip, the other ventral ending with two digitiform processes 
Version définitive du manuscrit publié dans / Final version of the manuscript published in :

Zootaxa, 2014, 3760(2), 289-300 http://dx.doi.org/10.11646/zootaxa.3760.2

(Fig 6). Vinculum thin with two membranous lobes at the articulation with the tegument (Fig 7). Aedeagus long and thin $(5.4 \mathrm{~mm})$, with vesica $5 \mathrm{~mm}$ long and lacking cornuti (Fig 3).

Etymology. The generic name is derived from the West Indies (=Caribbean)

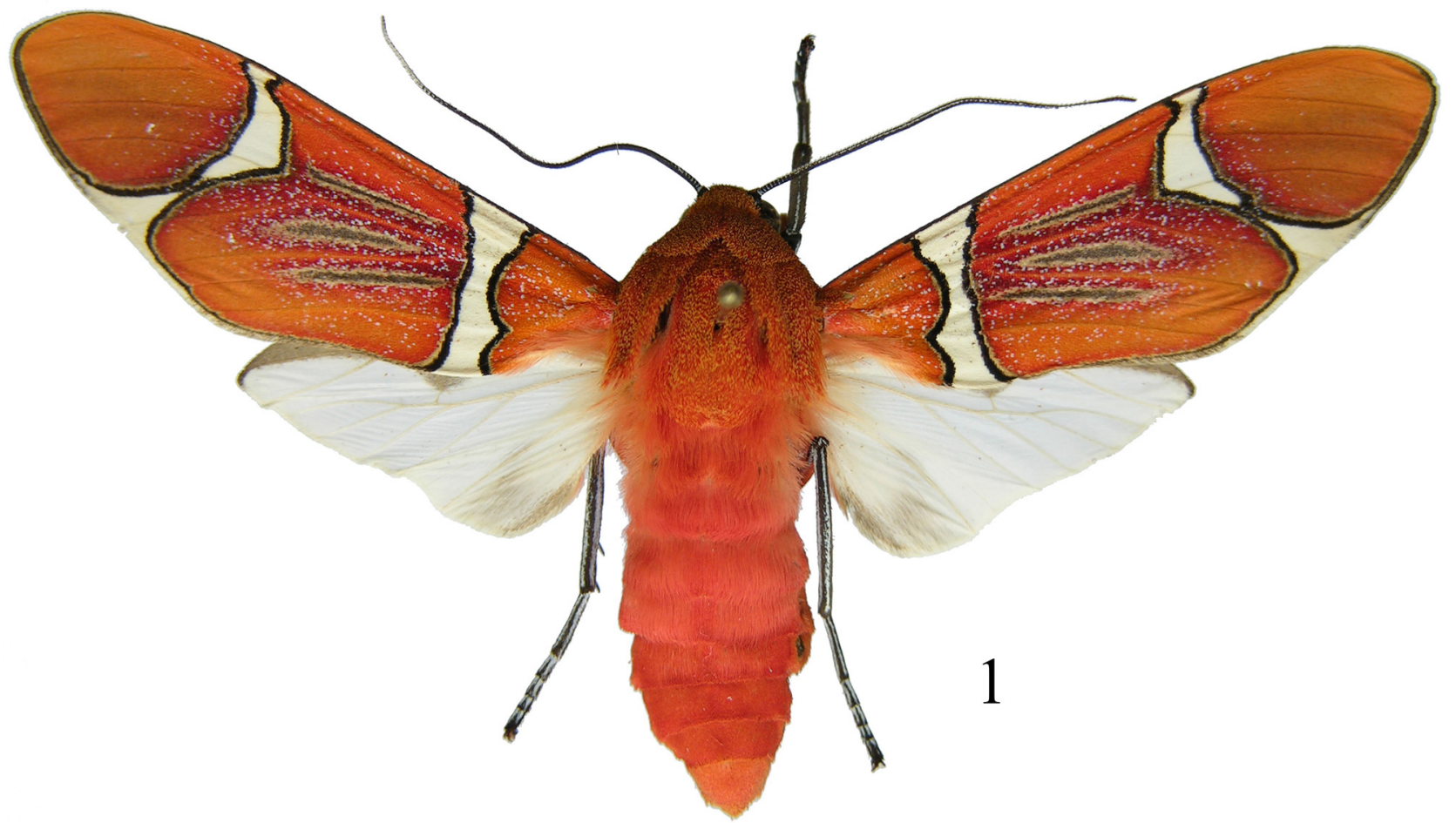

\section{$10 \mathrm{~mm}$}

FIGURES 1. Westindia haxairei n. sp. 1: Holotype, dorsal view.

\section{Westindia haxairei Vincent new species}

Figs. 1-6

Type material. Holotype; male: Dominican Republic, Monseñor Nouel department, Road El Blanco to Constanza pK 10, Reserva Scientifica Ebano Verde, alt. 1360m. N 19¹0.729’ W 70³0.988'; 15.viii.2007; attracted to UV light, J. Haxaire and O. Paquit leg.; genital prep. BV 372; Barcode SampleID/GenBank Acc.: BEVI0552/ KF930933: Deposited in the Muséum National d'Histoire Naturelle (MNHN, Paris). Allotype, female: same data as the holotype; genital prep. BV 373; Barcode SampleID/GenBank Acc.: BEVI0554/KF930920. Deposited in the Muséum National d'Histoire Naturelle (MNHN, Paris). Paratypes: 5 males and 4 females, same data as the holotype, 2 males with a barcode sequence available (SampleID/GenBank Acc.: BEVI0553/KF930928, BEVI0555/KF930922). Deposited in collections of the first author except for two specimens deposited respectively in the Natural History Museum (NHM, London) and the National Museum of Natural History (USNM, Washington D.C.); 2 males, same data as the holotype but collected on 08.viii.2007, in collection of the first author; 2 males, Dominican Republic, La Vega department, Road Valle Nuevo to Constanza Km 10, alt. 2015m. N 18 $50.123^{\prime}$ W 7041.677'; 05.viii.2007; attracted to UV light, J. Haxaire and O. Paquit leg., in collection of the first author. 2 males and 2 females, Dominican Republic, Monseñor Nouel, Cordillera Central, Casavito, 1050-1280m, vii.1999; 2 males and 2 females, Dominican Republic, Monseñor Nouel, Cordillera Central, La Palma de Constanza, 600m, vii.1999; R. Marx leg., in Museum Witt (München). 1 male Dominican Republic, Constanza, 1200m, 21.XI.1995, Westphal leg., in coll W. Speidel (München). 
Version définitive du manuscrit publié dans / Final version of the manuscript published in :

Zootaxa, 2014, 3760(2), 289-300 http://dx.doi.org/10.11646/zootaxa.3760.2
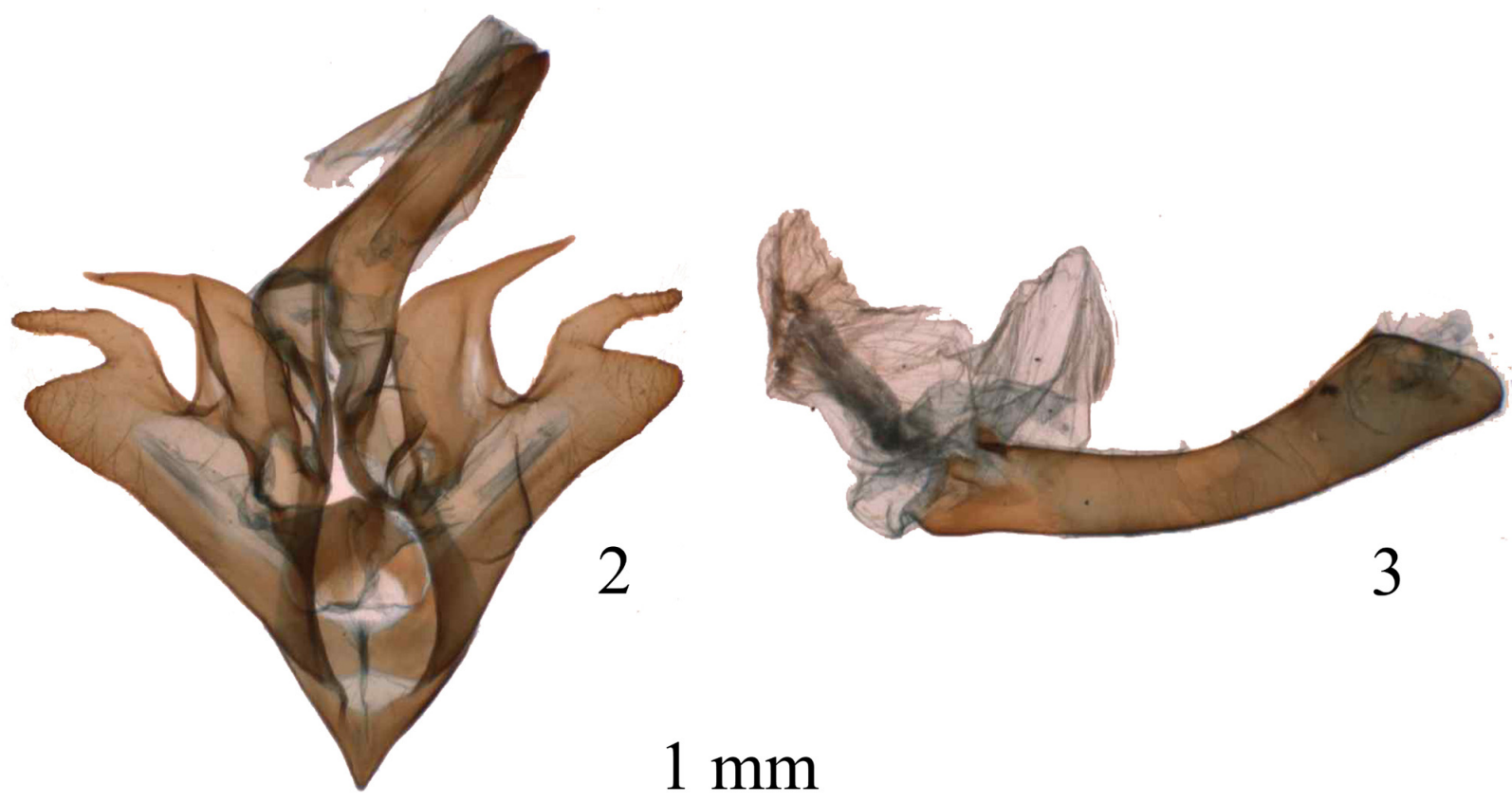

3

\section{$1 \mathrm{~mm}$}

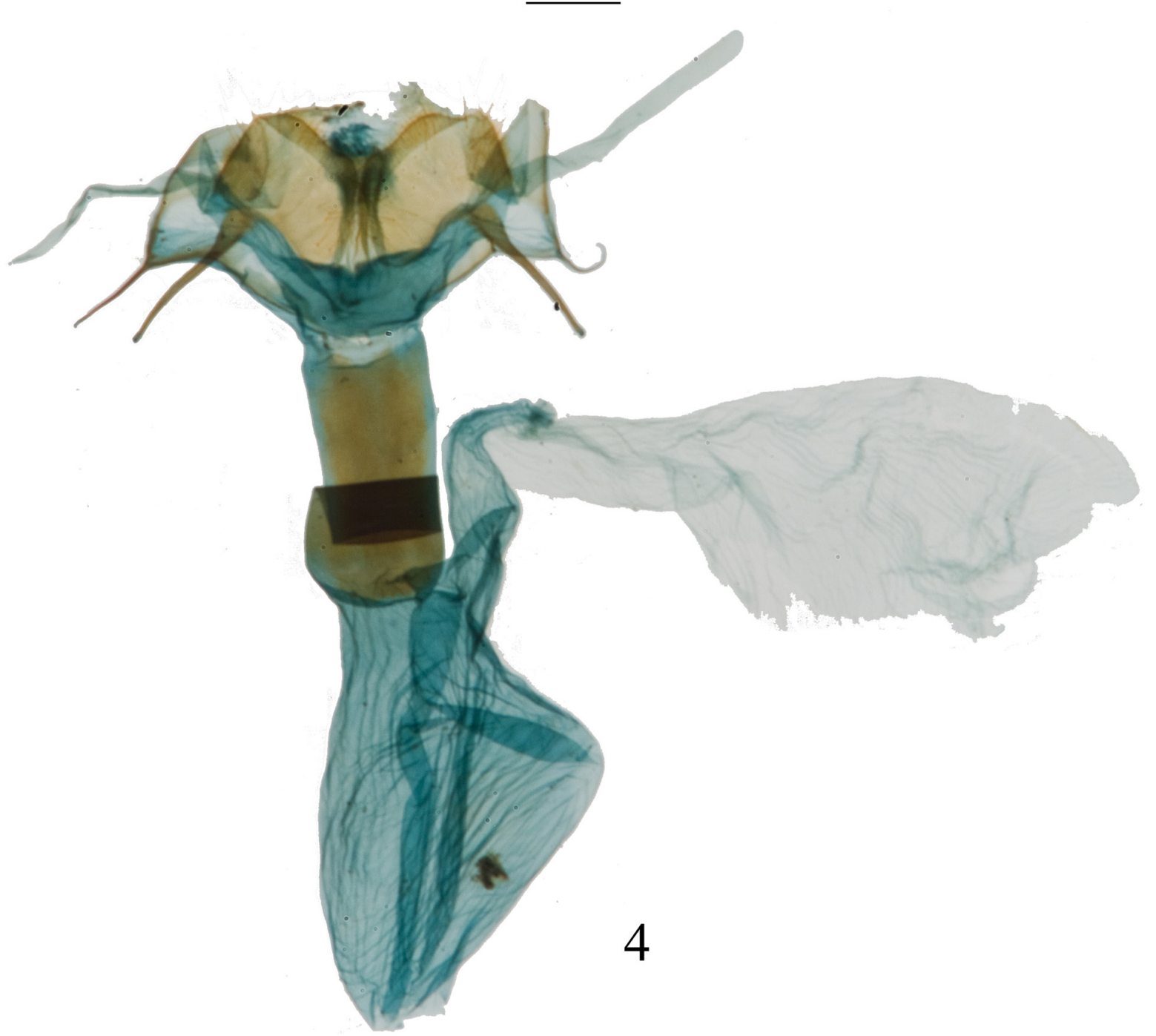

FIGURES 2-4. Westindia haxairei n. sp. 2: Holotype, genitalia ; 3: Holotype, aedeagus; 4: Paratype female, genitalia. 
Version définitive du manuscrit publié dans / Final version of the manuscript published in :

Zootaxa, 2014, 3760(2), 289-300 http://dx.doi.org/10.11646/zootaxa.3760.2
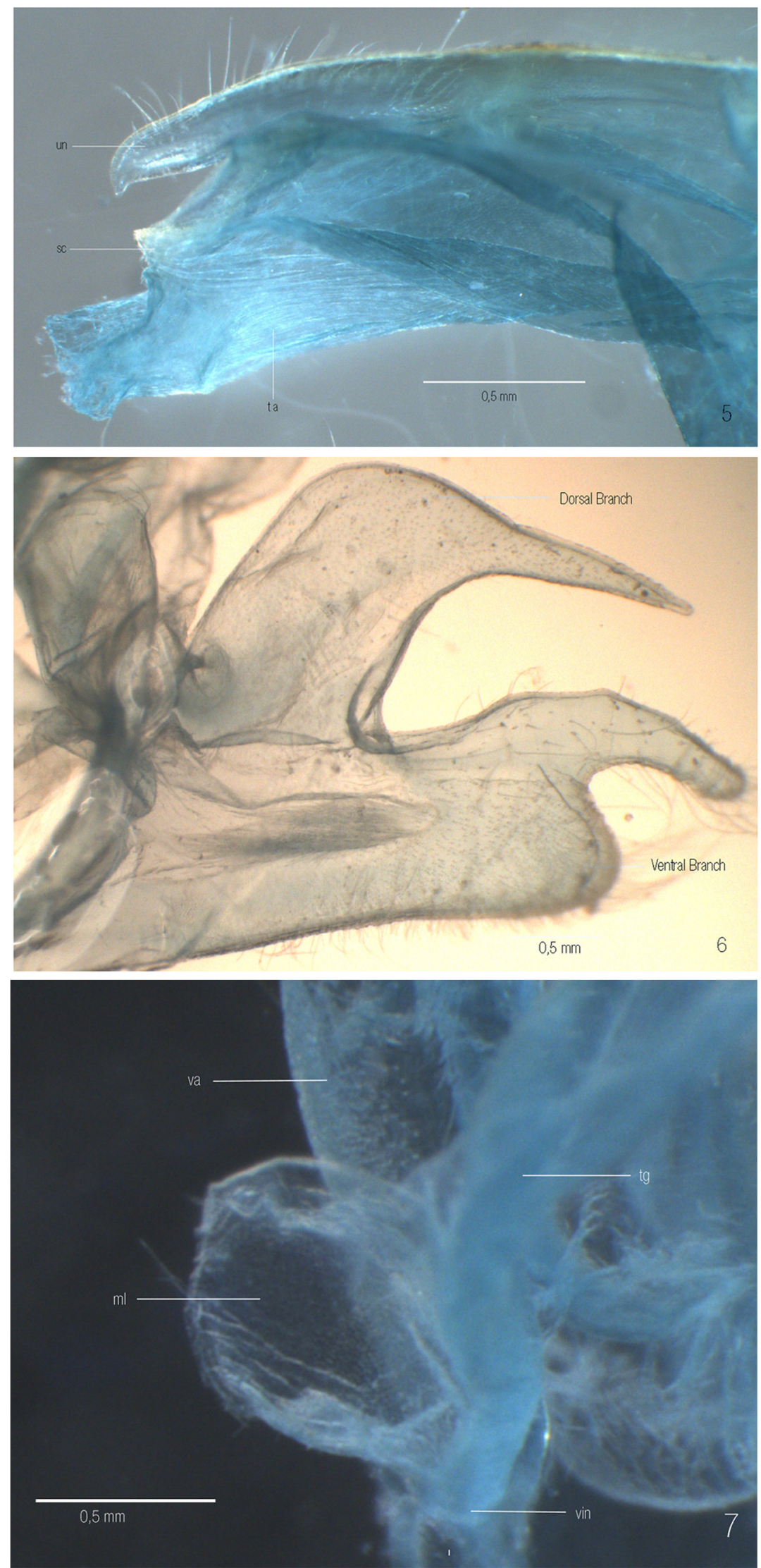

FIGURES 5-7. Westindia haxairei n. sp. 5 Holotype, genitalia, lateral view of the uncus (un), scaphium (sc) and tuba analis (ta) ; 6 Holotype, genitalia, valvae; 7 Holotype, genitalia, membranous lobe (ml) between vinculum (vin) and tegumen (tg), valvae (va). 
Version définitive du manuscrit publié dans / Final version of the manuscript published in :

Zootaxa, 2014, 3760(2), 289-300 http://dx.doi.org/10.11646/zootaxa.3760.2

Description. Male (Fig. 1) Wingspan 57-65 mm; forewing length 26-30 mm. Head Antennal scape spherical, pedicel narrow. Antennae monofiliform with 87 flagellomeres; dorsal and ventral surfaces black, delimited by a thin white line, except for the apical twenty flagellomeres white dorsally, and for the proximal ten segments with white scale patches on the distal end of each segment. The apical third with few bristles. Frons, head and labial palpi orange powdered with yellow. Thorax. All thorax, legs excepted, is orange powdered with yellow, as the result of the presence of long orange scales tipped with yellow, giving an orange powdered with yellow hue to the whole head and thorax. Ventral and dorsal surface the same color. Femur of all legs orange. Tibia and tarsi of the middle and hind legs black with dorsal surface streaked with two white longitudinal lines; area around the hindtibial spurs white. Fore-tibia and tarsi with a single white longitudinal line dorsally, tibia orange ventrally. Tarsal claw toothed. Forewing. Dorsum - Ground color orange with the central area more strongly colored with a vivid red hue, the proximal two thirds with opalescent scattered scales. The forewing is crossed by two transversal ivorywhite bands bordered by thick black lines. Antemedian band narrower in its central area; the postmedian band starts from the costa parallel to the antemedian band, then turns to reach the external margin of the wing in its middle; this second section of the band is strongly narrowed in its middle, where the black lines become almost fused, and it becomes wider when reaching the fringe which is white toward the anal angle and black toward the apex. The costa is marked by brownish scales. The central area of the forewing, between the two ivory-white bands, with three longitudinal grey streaks, slightly converging basally. The central grey coloration is surrounded by a thin yellowish area. Ventrum-Colors more vivid than on the dorsal face. The antemedian band is poorly contrasted, the postmedian interrupted at the costa and the three grey streaks not visible. Hindwing Dorsum - White and semihyaline. The anal area is slightly marked in grey; the costal area is grey with a similarly colored indentation toward the tip of the discal cell. Ventrum - Same coloration than dorsal face, but for the costa orange at its base and becoming grey toward its apex. Discoidal lunula grey. Abdomen. Tergites A1-4 covered by long vivid reddish orange scales. The posterior tergites with shorter scales and a slightly stronger coloration. Each spiracle is marked with black scales, forming a regular punctuation along the pleurites. Sternites uniformly vivid orange. Ventral surface identical in color. Male genitalia (Figs. 2-3; 5-6) Tegumen and Uncus narrow and elongated. Uncus with a pointed apex slightly curved ventrally. It is covered by long bristles laterally. Anal tube slightly sclerotized laterally. Scaphium sclerotized, concave and tongue-shaped (Fig. 5). Transtilla subrectangular. Valves large, symmetrical, bifid with a deep notch (Fig. 6). The dorsal branch is long and curved with a very pointed tip. Ends of the ventral branch with two digitiform processes: one broad and rounded, the other fine and curved with some bristle at the end. Vinculum with a short pointed saccus. Juxta slightly sclerotized with a U-shaped excavation on the ventral margin. Phallus long, slightly curved. Caecum penis short and rounded. Vesica with a single lobe lacking cornuti (Fig. 3). Female. The female is identical to the male but for the absence of a dense tuft of golden bristles on the ventral face of the flagellomeres. Female genitalia (Fig. 4). Tergite A7 twice as wide as tergite A6, slightly sclerotized and rectangular. Sternite A7 large with a strong V-shaped posterior indentation. Pseudopapillae entirely joined and covered with short bristles. Ductus bursae uniformly sclerotized, elongated, ribbon shaped, curved near the insertion of the corpus bursae which shape is pyriform, wrinkled and without signum. There is a protuberance close to the insertion of the ductus bursae. The ductus seminalis is short, opening into a large wrinkled and rounded bulla seminalis. Papillae anales trapeziform, uniformly covered with long bristles. Dorsal pheromone glands with a pair of long unbranched tubes.

Variation. The postmedian band exhibits some variations in the extent of its central contraction. Some specimens display a $1 \mathrm{~mm}$ interruption of this band whereas in others the contraction is almost absent allowing a continuous ivory-white coloration.

Etymology. The new species is dedicated to our colleague Jean Haxaire.

Distribution, phenology and biology. W. haxairei seems restricted to middle elevation localities of the central cordillera in the Dominican Republic. All the specimens known to us were collected in July and August, and this species was not collected during previous sampling in the same area during April/May 2004, suggesting that Westindia is a mid-summer flier. The early stages and foodplants are unknown.

\section{Discussion}

All the phylogenetic hypotheses generated from the combined datasets consistently support the placement of the new genus Westindia within the subtribe Phaegopterina, in agreement with our morphological observations. 
Version définitive du manuscrit publié dans / Final version of the manuscript published in :

Zootaxa, 2014, 3760(2), 289-300 http://dx.doi.org/10.11646/zootaxa.3760.2

However, the monophyly of the subtribe was only poorly supported after ML and MP analyzes (bootstrap support of 65 and 55, respectively) of the reduced dataset with representatives of the PPCE clade only (Fig. 8). The analysis of the extended dataset (including all tribes in Arctiinae) did not recover a monophyletic Phaegopterina subtribe (Fig. 9) but still consistently placed Westindia haxairei among members of this subtribe in all analyses. Separate gene analyses (results not shown) produced generally unresolved trees with poorly supported groupings, with the noticeable exception of subtribe Arctiina for which no $28 \mathrm{~S}$ sequences were available and which is consistently supported as monophyletic by COI sequences alone (BS of 83 after ML analysis with the nt12/nt 3 partition of the COI sequences, results not shown). Overall, and as could be expected, the limited taxon and gene sampling results in limited resolution of the phylogenetic relationships within the subfamily Arctiinae, with generally poor statistical support for most branches. Considering that the phylogeny of these moths has to date received relatively little attention, it is worth noting that these genes support the monophyly of subtribes Arctiina, Pericopina and Ctenuchina (Fig. 9), as well as the monophyly of Ctenuchina + Euchromiina. The position of genus Melese Walker, 1854 , as inferred from our analyses, confirms its outlier status within the subtribe Phaegopterina, as already noted by Jacobson \& Weller (2002).

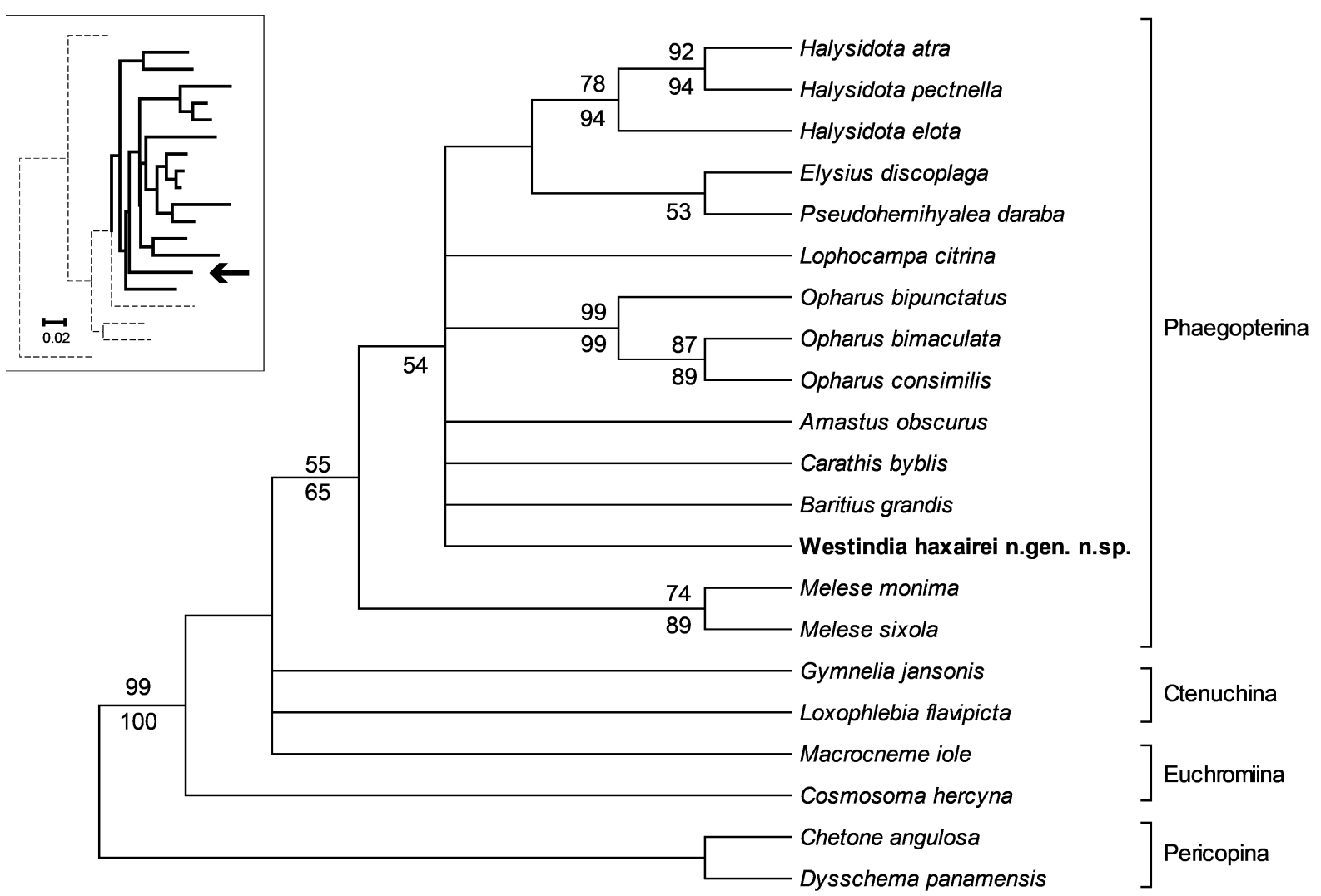

FIGURE 8. Consensus tree of the four most parsimonious trees obtained after the parsimony analysis of dataset (1) combining both COI and 28S genes for 21 ingroup taxa (outgroup Helicoverpa armigera, not shown). Bootstrap confidence values over $50 \%$ are given above branches. The tree in the upper-left box represents the topology of the best-score ML tree in which the Phaegopterina clade is highlighted in black and an arrow points at Westindia haxairei n. sp.. ML bootstrap values are given below branches on the MP tree for shared nodes.

The discovery of this new arctiine moth in the Dominican Republic came as a surprise in a region regularly prospected by entomologists for several centuries. In fact, no species known to us bears any close similarity in wing pattern to Westindia haxairei. Both Ammalo helops (Cramer, [1776]) and Elysius cingulata (Walker, 1856) have a yellowish abdomen with black transverse bands, but the forewings are brown and do not have bright transverse bands, and the hind wings have yellowish to pinkish coloration (never white). The genus Pseudamastus Toulgoët, 1985, has two subspecies $P$. alsa alsa (Druce, 1890) and P. alsa lalannei Toulgoët, 1985 described from Dominica and Martinique, respectively, but the forewings are uniformly brown or yellowish, without ornamentation; the male genitalia figured by Toulgoët (1985) are quite different, notably in the valves and uncus. Species of Halysidota Hübner, [1819], of which several occur in the Caribbean (H. cinctipes Grote, [1866], H. ata 
Version définitive du manuscrit publié dans / Final version of the manuscript published in :

Zootaxa, 2014, 3760(2), 289-300 http://dx.doi.org/10.11646/zootaxa.3760.2

Watson, 1980, H. insularis (Rothschild, 1909), and H. elota (Möschler, 1886)), have forewings similar in size and shape to those of Westindia, but none has similar color and ornamentation (e.g., yellow to brown forewings, except Halisidota masoni; presence of a reniform mark) nor abdominal color; male genitalia of Halysidota figured by Watson (1980) have a vinculum with digitate, non-setose processes on each side at the junction with the tegument, and these processes are absent in W. haxairei. Among the Central American species, Halysidota masoni (Schaus, 1895), described from Mexico, is somewhat similar to W. haxairei in having an orange background color of the body and forewings and a comparable wingspan, but the presence of a black spot on each tegulae and a large yellowish grey-white subterminal band separates them. Lastly, species of Gorgonidia Dyar, 1898 have wing colors and patterns reminiscent of $W$. haxairei, but these all differ by the presence of three incomplete yellow bands (basal, antemedial and postmedial) on the forewings and a grey patch extending from the apex of the discal cell to the outer margin of the forewing (see Vincent 2012).

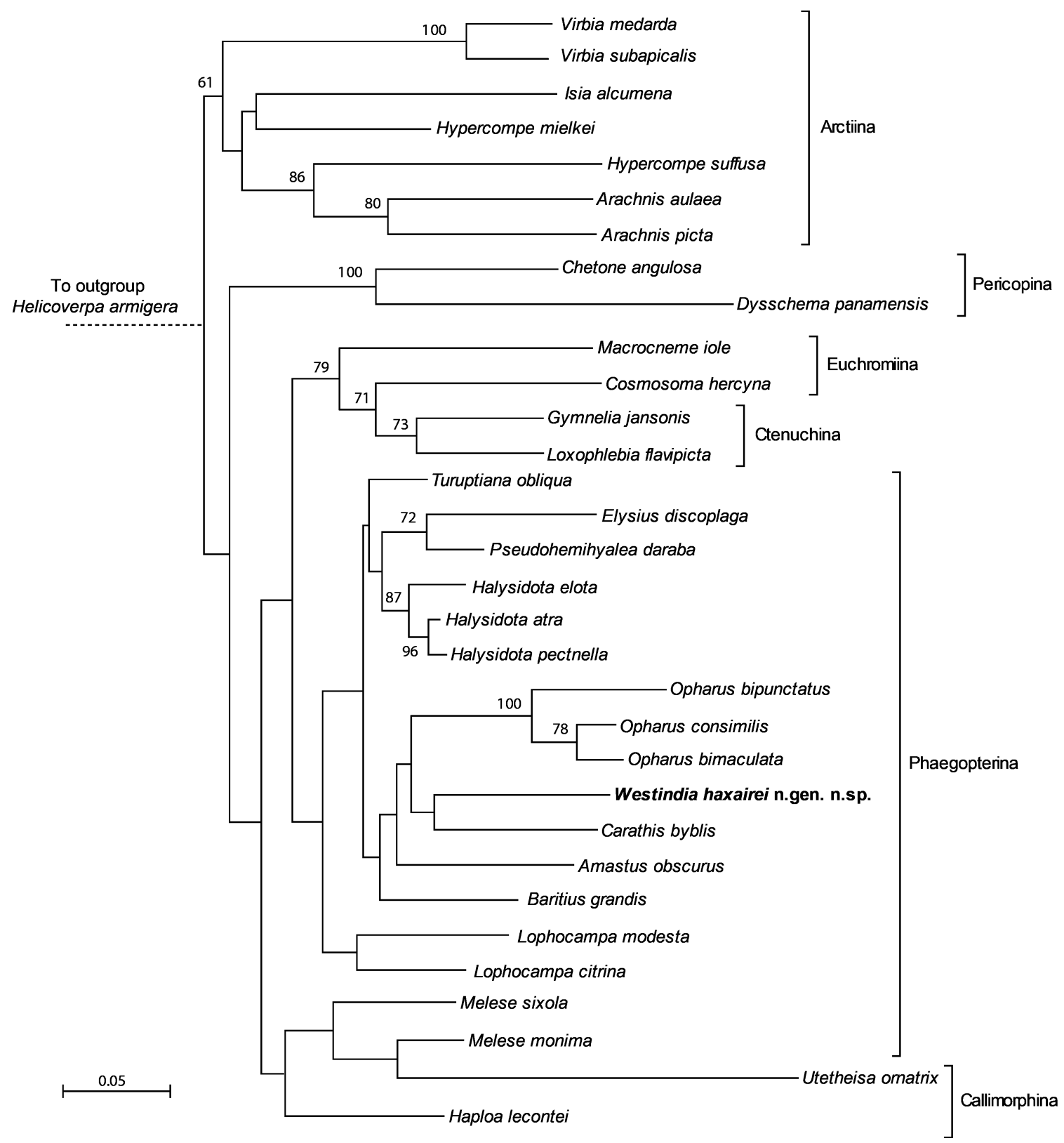

FIGURE 9. Best-score ML tree resulting from the analysis of the extended dataset (2) with the two genes as distinct partitions. Bootstrap confidence values over $50 \%$ are given at each node.

The unique and distinctive features of Westindia haxairei make it difficult to propose a known arctiine genus as a closest relative, although our analyses highlighted characters useful at higher taxonomic levels. Westindia possesses two of the three character conditions proposed by Jacobson \& Weller (2002) to define the subtribe 
Version définitive du manuscrit publié dans / Final version of the manuscript published in :

Zootaxa, 2014, 3760(2), 289-300 http://dx.doi.org/10.11646/zootaxa.3760.2

Phaegopterina: (1) the presence on the tympanum of a ventrally closed pocket IV; and (2) the hindwing vein Sc+R1 much attenuated toward the hindwing margin (which we consider fitting the condition described by Jacobson \& Weller (2002) as "vein Sc+R1 [...] present but does not reach the hindwing margin"). The third character (presence of prothoracic glands) was not observed and their absence may represent a secondary loss as in the phaegopterine genus Leucanopsis Rego Barros, 1956 (Jacobson \& Weller, 2002). The presence of a largely rounded diverticuleshaped bulla seminalis is comparable to that described by Bendib (1998) as a diagnostic feature of the Halysidota group or Phaegopterina. In addition, the quadrifid venation in hindwings (vein M2 present and branching from the lower angle of the discal cell) and the pseudo-papillae of female genitalia fused throughout their length support the placement of Westindia in a lineage defined by Bendib (1998: 167) that includes the genera Hemihyalea, Halysidota, Praeamastus, Elysius and Amastus. The configuration of dorsal saccular glands, proposed by Bendid (1998) to further infer the relationships within this lineage, is of type "1" in Westindia haxairei ("a pair of elongate glands with fairly wide opening"), a condition found in many Phaegopterina (Bendib \& Minet, 1998) and uninformative at this stage with respect to phylogenetic inferences within the tribe. The possible relationship between Westindia haxairei and the genus Carathis, as apparent in Fig. 9 (with no statistical support), was ruled out after morphological comparison with two species occurring in Cuba (C. gortynoides Grote, 1866 and C. alayorum Becker, 2011). In the current state of knowledge, a more precise placement of Westindia must await further taxon and character sampling.

\section{Acknowledgements}

The first author is grateful to Jean Haxaire and Odile Paquit who collected the specimens of this new genus and offered the material for study, and to Joël Minet (Muséum national d'Histoire Naturelle, Paris) for his help in the observation and interpretation of some characters. DNA barcode data were generated at the Canadian Centre for DNA barcoding hosted by the Biodiversity Institute of Ontario, University of Guelph (Canada), through funding by NSERC, Genome Canada and the Ontario Genomics Institute. Sequences of Costa Rican taxa used for the phylogenetic analyses were generated as part of a joint research project between Mehrdad Hajibabaei, Daniel H. Janzen and Winnie Hallwachs on the lepidopteran diversity in Area de Conservacion Guanacaste (ACG) in Costa Rica.

\section{Literature cited}

Abraham, D., Ryrholm, N., Wittzell, H., Holloway, J.D., Scoble, M.J. \& Löfstedt, C. (2001) Molecular Phylogeny of the Subfamilies in Geometridae (Geometroidea: Lepidoptera). Molecular Phylogenetics and Evolution, 20, 65-77.

Bendib, A. (1998) Contribution à l'étude des Arctiidae (Lepidoptera : Noctuidea): phylogénie et morphologie de l'abdomen des femelles. Thèse de doctorat du Muséum National d'Histoire Naturelle, spécialité Entomologie, 300 pp.

Bendib, A \& Minet, J. (1998) Female pheromone glands in Arctiidae (Lepidoptera). Evolution and phylogenetic significance. Comptes rendus de l'Académie des sciences. Série 3, Sciences de la vie, 321 (12), 1107-1114.

DaCosta, M.A. \& Weller, S.J. (2005) Phylogeny and classification of the Callimorphini (Lepidoptera: Arctiidae:Arctiinae). Zootaxa, 1025, 1-94.

Haxaire, J. \& Schmit, P. (2001) Un nouveau sphingide de Republique Dominicaine: Cauthetia carsusi (Lepidoptera Sphingidae). Lambillionea, 101 (4), 605-608.

Hebert, P.D.N., Dewaard, J.R. \& Landry, J.F. (2010) DNA barcodes for 1/1000 of the animal kingdom. Biology Letters, 6, 359-362. http://dx.doi.org/10.1098/rsbl.2009.0848

Huber, B.A., Fischer, N. \& Astrin, J.J. (2010) High level of endemism in Haiti's last remaining forests: a revision of Modisimus (Araneae: Pholcidae) on Hispaniola, using morphology and molecules. Zoological Journal of the Linnean Society, 158, 244-299. http://dx.doi.org/10.1111/j.1096-3642.2009.00559.x

Jacobson, N.L. \& Weller, S.J. (2002) A cladistic study of the Arctiidae (Lepidoptera) by using characters of Immatures and Adults. Thomas Say Monograph Series, Entomological Society of America, 98 pp.

Klots, A.B. (1970) Lepidoptera. In: Tuxen, S.L. (Ed.), Taxonomist's glossary of genitalia of insects. Copenhagen, Munksgaard, pp. 115-130.

Lafontaine, J.D. \& Schmidt, B.C. (2010) Annotated check list of the Noctuoidea (Insecta, Lepidoptera) of North America north of Mexico. Zookeys, 40, 1-239.

http://dx.doi.org/10.3897/zookeys.40.414 
Version définitive du manuscrit publié dans / Final version of the manuscript published in :

Zootaxa, 2014, 3760(2), 289-300 http://dx.doi.org/10.11646/zootaxa.3760.2

Miller, J.S. (1991) Cladistics and classification of the Notodontidae (Lepidoptera : Noctuoidea) based on larval and adult morphology. Bulletin of the American Museum of Natural History, 204, 1-230.

Miller, M.A., Holder, M.T., Vos, R., Midford, P.E., Liebowitz, T., Chan, L., Hoover, P. \& Warnow, T. (2009) The CIPRES Portal [Online]. Available from: http://www.phylo.org (accessed 24 August 2011)

Pattengale, N.D., Alipour, M., Bininda-Edmonds, O.R.P., Moret, B.M.E. \& Stamatakis, A. (2010) How many bootstrap replicates are necessary? Journal of Computational Biology 17, 337-354.

http://dx.doi.org/10.1089/cmb.2009.0179

Perez-Gelabert, D.E. (2008) Arthropods of Hispaniola (Dominican Republic and Haiti) : A checklist and bibliography. Zootaxa, 1831, 530pp.

Rawlins, J.E. \& Miller, J.S. (2008) Dioptine moths of the caribbean region: Description of two new genera with notes on the biology and biogeography (Lepidoptera: Notodontidae: Dioptinae). Annals of Carnegie Museum, 76 (4), $203-225$. http://dx.doi.org/10.2992/0097-4463(2008)76[203:dmotcr]2.0.co;2

Rougerie, R \& Herbin, D. (2006) Hispaniodirphia lemaireiana n. sp., a new saturniid from the Greater Antilles (Lepidoptera:Saturniidae, Hemileucinae). Zootaxa, 1204, 53-59.

Santiago-Valentin, E. \& Olmstead, R. (2004) Historical biogeography of Caribbean plants: introduction to current knowledge and possibilities from a phylogenetic perspective. Taxon, 53, 299-319. http://dx.doi.org/10.2307/4135610

Saux, C., Fisher, B.L. \& Spicer, G.S. (2004) Dracula ant phylogeny as inferred by nuclear 28S rDNA sequences and implications for ant systematics (Hymenoptera: Formicidae: Amblyoponinae). Molecular Phylogenetics and Evolution 33, 457-468. http://dx.doi.org/10.1016/j.ympev.2004.06.017

Stamatakis, A. (2006) RAxML-VI-HPC:Maximum Likelihood-based Phylogenetic Analyses with Thousands of Taxa and Mixed Models. Bioinfomatics, 22, 2688-2690. http://dx.doi.org/10.1093/bioinformatics/bt1446

Stamatakis, A., Hoover, P. \& Rougemont, J. (2008) A Fast Bootstrapping Algorithm for the RAxML Web-Servers. Systematic Biology, 57, 758-771.

Tamura, K., Peterson, D., Peterson, N., Stecher, G., Nei, M. \& Kumar, S. (2011) MEGA5: Molecular Evolutionary Genetics Analysis using Maximum Likelihood, Evolutionary Distance, and Maximum Parsimony Methods. Molecular Biology and Evolution, 28 (10), 2731-2739.

http://dx.doi.org/10.1093/molbev/msr121

Thiaucourt, P. (2006) Antillisa gen. n., définition et notes sur les espèces appartenant à ce genre (Notodontidae). Lépidoptères, $4(1), 1-8$.

Toulgoët, H. de (1985) Description d'une nouvelle sous-espèce d'Arctiide de la Martinique avec création d'un genre nouveau. (18 note), (Lepidoptera, Arctiidae). Nouvelle Revue d'Entomologie, (N.S.) 2 (1), 5-9.

Vaglia, T., Haxaire, J., Kitching, I.J., Meusnier, I. \& Rougerie, R. (2008) Morphology and DNA barcoding reveal three cryptic species within the Xylophanes neoptolemus and loelia species-groups (Lepidoptera: Sphingidae). Zootaxa, 1923, 18-36.

Vincent, B. (2005a) Description de deux nouvelles espèces d'Arctiidae de République Dominicaine (Arctiidae, Phaegopterinae). Lépidoptères, 3 (1), 1-8.

Vincent, B. (2005b) Description de trois nouveaux Lophocampa Harris de République Dominicaine (Arctiidae, Phaegopterinae). Lépidoptères, 3 (2), 9-18.

Vincent, B. (2006) Description d'une deuxième espèce du genre Caribarctia Ferguson de République Dominicaine (Lepidoptera, Arctiidae). Bulletin de la Société Entomologique de France, 111 (2), 223-226.

Vincent, B. (2009) Description de deux nouvelles espèces appartenant au genre Lophocampa Harris, 1841 (Lepidoptera Arctiidae). L'entomologiste, 65 (1), 47-53.

Vincent, B. (2011) Description of two new Lophocampa Harris from the Dominican Republic (Arctiidae, Arctiinae). Zookeys, $75,69-77$. http://dx.doi.org/10.3897\%2Fzookeys.75.811

Vincent, B. (2012) A review of the genus Gorgonidia Dyar, 1898, with the description of one new species (Lepidoptera: Erebidae, Arctiinae, Arctiini). The European Entomologist, 4 (1), 33-54.

Vincent, B, Laguerre, M \& Rougerie, R (2009) Contribution à la connaissance du genre Opharus Walker avec description de deux nouvelles espèces. Apport des codes barres ADN (Lepidoptera Arctiidae). Bulletin de la Société Entomologique de France, 114 (1), 69-78.

Watson, A (1980) A revision of the Halysidota tesselaris species-group (Halysidota sensu stricto) (Lepidoptera: Arctiidae). Bulletin of the British Museum (Natural History). (Entomology) Suppl. 40 (1), 1-65.

Young, C.J. (2006) Molecular relationships of the Australian Ennominae (Lepidoptera: Geometridae) and implications for the phylogeny of the Geometridae from molecular and morphological data. Zootaxa, 1264, 1-147.

Zaspel, J.M. \& Weller, S.J. (2006) Review of generic limits of the tiger moth genera Virbia Walker and Holomelina HerrichSchäffer (Lepidoptera: Arctiidae:Arctiinae) and their biogeography. Zootaxa, 1159, 1-68.

Zahiri, R., Holloway, J.D., Kitching, I.J., Lafontaine, J.D., Mutanen, M. \& Wahlberg, N. (2012) Molecular phylogenetics of Erebidae (Lepidoptera, Noctuoidea). Systematic Entomology, 37 (1), 102-124.

http://dx.doi.org/10.1111/j.1365-3113.2011.00607.x 